\title{
Lymphoscintigraphy in Breast Cancer: A Short Review about the Impact on Upper Limb after Surgical Treatment
}

\author{
Anke Bergmann $^{1} *$, Juliana Miranda Dutra de Resende $^{1}$, Sebastião David Santos-Filho ${ }^{2}$, \\ Marcelo Adeodato Bello ${ }^{1}$, Juliana Flavia de Oliveira ${ }^{1}$, Christopher J. Palestro ${ }^{3}$ and Mario \\ Bernardo-Filho ${ }^{1,2}$ \\ ${ }^{1}$ Instituto Nacional do Câncer; Praça Cruz Vermelha, 23; 20230130; Rio de Janeiro - RJ - Brasil. ${ }^{2}$ Departamento \\ de Biofísica e Biometria; Laboratório de Radiofarmácia Experimental; Instituto de Biologia Roberto Alcantara \\ Gomes; Universidade do Estado do Rio de Janeiro; Av. 28 de setembro, 87; $4^{\circ}$ andar; 20551030; Rio de Janeiro - \\ $R J$ - Brasil. ${ }^{3}$ Albert Einstein College of Medicine of Yeshiva University and Division of Nuclear Medicine and \\ Molecular Imaging; North Shore Long Island Jewish Health System, Manhasset and New Hyde Park, NY - USA
}

\begin{abstract}
Breast cancer is still associated with high mortality rates and one of the most important factors governing long survival is accurate and early diagnosis. In underdeveloped countries, this disease frequently is only detected in advanced stages; however, through mammography, many women have been diagnosed at early stages. In this context, the sentinel lymph node (SLN) technique is associated with less postoperative morbidity compared to axillary lymphadenectomy. Lymphoscintigraphy has emerged as a method for the evaluation of lymphatic drainage chains in various tumours, being both accurate and non invasive. The aim of this work is to present the main aspects which cause controversy about SLN and lymphoscintigraphy and the impact that these procedures have had on lymphedema after surgical treatment for breast cancer. A short review including papers in English, Spanish and Portuguese, available on Lilacs and Medline database, published between January, 2000 and July, 2008 was performed. The key words breast cancer, lymphoscintigraphy, SLN biopsy, lymphedema were used. Various studies have aimed to compare the incidence and prevalence of lymphedema according to the technique used; however, the population subjected to SLN is different from the one with indication for axillary lymphadenectomy regarding staging. Moreover, little is known about long term morbidity since it is a relatively new technique. In conclusion, the development of surgical techniques has permitted to minimize deformities and the current trend is that these techniques be as conservative as possible. Thus, lymphoscintigraphy plays an important role in the identification of $S L N$, contributing to the prevention and minimization of postoperative complications.
\end{abstract}

Key words: Breast cancer, lymphoscintigraphy, Sentinel Lymph node Biopsy, lymphedema

\section{INTRODUCTION}

The annual incidence of breast cancer has been increasing exponentially causing a great impact on health public policies. Therefore early detection is a critical factor for an efficient prognostic and long survival (INCa, 2008). Due to this fact, breast cancer is still the theme of research that aims to elucidate exhaustively new clinic-surgical approaches which result in efficient treatment and achieve the final objective: the locoregional control of the disease and its metastases with an increase in the survival, reduced morbidity and reduced impact on the quality of life. Although cancer is often only diagnoses in its later stages in underdeveloped countries, recently, with the aid of mammographic scanning programs, many women have been diagnosed with tumors at early stages 
and many conservative surgeries were done even though the radical surgeries with axillary lymphadenectomy prevailed (Sado, 2006).

The key to determining the treatment of breast cancer is the stage of the disease and the patient's clinical condition, the status of axillary lymph nodes being fundamental due to its clinical importance to cancer dissemination. Moreover, it is considered the most important factor of prognostic and one of the recommendation criteria for the implementation of local or systemic therapy (Vigário et al., 2003; James and Edge, 2006).

Historically, the standard procedure for obtaining information about axillary node involvement has been the axillary lymphadenectomy, which is responsible for substantial morbidities, short and long term, such as sensitivity alterations, nervous injury, motor dysfunctions and risk of developing lymphedema which contributes to functional loss, infections of the ipsilateral upper-limb to axillary and other complications (James and Edge, 2006).

With the introduction of the sentinel lymph node (SLN) biopsy, less postoperative morbidities are expected since the selective excision of lymph nodes that receive lymphatic drainage from the breast firstly cause less axillary impacts. The SLN biopsy also avoids unnecessary emptying and postoperative complications (Massod, 2006; Bowers et al., 2006). It presumably predicts the involvement of the remaining drainage chain, since it is the most likely place to disseminate neoplastic cells (Sado, 2006).

Gould et al. (1960) described the term "sentinel lymph node" in relation to parotid cancer and Cabanas (1977) published the prognostic value of SLN for the treatment of penile cancer which was later applied to melanoma. However, the technical application for breast cancer appeared some time later and the optimal method is still under discussion (James and Edge, 2006; Gould et al., 1960; Cabanas, 1977).

In this context, lymphoscintigraphy emerged as a method for the evaluation of drainage chains in different tumours. It is safe and simpler and less invasive than lymphangiography and the main aim is to map and to allow the study of the lymphatic drainage of a specific location - especially when there are inaccessible lymphatic channels through the prescription of radiopharmaceuticals compatible with the biological mechanism of interest. Studies have analyzed its efficacy mainly in the preoperative period and for the study of lymphedema, but controversies remain McMasters et al., 2000; Czerniecki et al., 2001). This work reviews the main aspects which cause controversy in relation to SLN and lymphoscintigraphy and its impact on lymphedema after the surgical treatment of breast cancer.

\section{METHODOLOGY}

A literature review, including papers in English, Spanish and Portuguese, available on Lilacs and Medline database, published between January, 2000 and July, 2008 was performed. The keywords breast cancer, lymphoscintigraphy, Sentinel Lymph node Biopsy, lymphedema were used.

Original papers, which discussed the indications and complications of SLN lymphoscintigraphy for the treatment of breast cancer were also selected. These results should help readers understand the utilization of SLN, the introduction of lymphoscintigraphy and the reported morbidities after the surgical treatment of breast cancer.

\section{RESULTS AND DISCUSSION}

In order to perform the SLN technique, the most commonly used procedure was the injection into mammary tissue of vital dye isosulfan blue and the colloidal agent labeled with technetium-99m $\left({ }^{99 \mathrm{~m}} \mathrm{Tc}\right)($ Sado, 2006).

In the operative suite, the identification of lymph node is usually visual by staining of the tissue or detection with gamma-probe. Every lymph node which traps the radiopharmaceutical must be resected, and may vary in number from 3 to 5 (James and Edge, 2006). However, King et al. (2004) report that isosulfan blue dye may cause allergic reactions of varying severity such as urticaria, general rash and pruritis ( $1^{\text {st }}$ degree), hypotension $\left(2^{\text {nd }}\right.$ degree $)$ and need for pressure support pressure $\left(3^{\text {rd }}\right.$ degree), the last occurring only rarely. The reactions are associated with the injected volume. New studies to evaluate the least volume that maintains the safety of the procedure without compromising its success, are necessary (King et al., 2004).

On the other hand, there are no studies about allergic reactions to ${ }^{99 \mathrm{~m}}$ Tc-colloid. Hence, new agents are examined with the intention of selecting 
the only lymph nodes with metastasis. The long term impact of these reactions has not been studied yet (James and Edge, 2006).

Regarding the injection site, as soon as SLN started to be used, the most typical type of injection was the peritumoral. However, subsequent studies showed that the periareolar was more accurate and more reliable for the identification of SL with a lower false negative rate. Another issue to be taken into account is the fact that isosulfan blue dye is rapidly absorbed by lymph nodes and is generally injected 5-10 minutes before the surgery. The radiolabeled colloid, however, needs to be absorbed and may be injected several hours or even the day before surgery. Other factor which influences the detection of SL is an increased incidence of false negative results when the procedure is performed by an inexperienced surgeon (James and Edge, 2006; Czerniecki et al., 2001). Fig. 1 shows a lymphoscintigraphy of breast carcinoma.

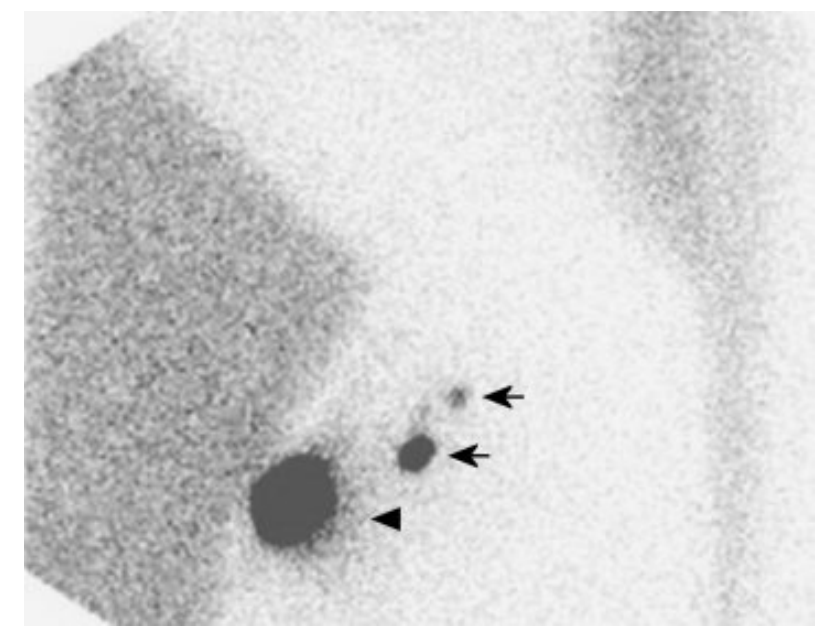

Figure 1 - Lymphoscintigraphy in breast carcinoma: Left lateral view shows two foci of tracer accumulation (arrows) in the left axilla, indicating the location of the sentinel nodes. The intense focus in the left breast is the injection site (arrowhead).

Once the SL is excised, the lymph node freezing technique may be used for cytological analysis; however, there are advantages and limitations. One of the limitations is that this process may cause tissue changes or losses during the process, interfering in the diagnosis (Massod, 2006). On the other hand, there are studies which do not find differences between this technique and the cytological analysis.

According to James and Edge (2006), around 40\% of the positive lymph nodes are not detected in the intraoperative period due to the presence of micrometastases. The standard, according to Massod (2006) would be that the pathologist had access to the material of the primary core before SLN interpretation, so that he could be familiar with the histological and biological appearance of the injury (James and Edge, 2006; Massod, 2006). Consequently, lymphoscintigraphy has been used to help SLN mapping, even though its value is still a matter for debate. Although almost all SLN are located in the axilla, in some patients drainage is to the lymph nodes located in the internal mammary chain. This is more common when the tumour is in the internal quadrant. This study of these lymph nodes has limited functions for some groups since they do not decrease false negative rates and increase institutional costs for the procedure. Besides, the gamma-probe method may not be able to identify the SLN (McMasters et al., 2000).

Nevertheless, in conformity to Czerniecki et al. (2001), the study of these lymph nodes provides additional information which complements the prognosis in some of the patients. Furthermore, the study may help to limit the extent of axillary dissection and also affect adjuvant systemic therapy and radiotherapy with tumours of $2 \mathrm{~cm}$ (Czerniecki et al., 2001; Noguchi et al., 2004). 
In order to bring evidence about alterations after surgery, another lymphoscintigraphy was performed postoperatively. Some studies detected alterations in the breast and thoracic wall drainage after axillary lymphadenectomy and/ or after radiotherapy in the axilla with a change in the lymphatic path to the contralateral axilla. These findings are fundamental to the explanation of contralateral metastases, with or without disease remaining on the ipsilateral breast or on the thoracic wall and to define risk node groups regarding cancer dissemination (Filippakis and Zografos, 2007; Olmos et al., 1999). Authors also have confirmed the use of lymphoscintigraphy in the prevention of lymphedema after breast cancer (Krynycki et al., 2005).

The eligibility criteria for SLN are generally breast cancer of $3 \mathrm{~cm}$ or less and clinically negative axilla. The value for patients with ductal carcinoma in situ is extremely controversial because of the reduced morbidity of SLN and metastatic disease found in these patients (Massod, 2006; Noguchi et al., 2004). Another discussion is the elimination or not of SLN before neoadjuvant chemotherapy, because there may be a complete response with regression in the metastases of some lymph nodes, but the disease may remain in other ones (Noguchi et al., 2004).

In contrast, Vigário et al. (2003), reported that the accuracy of axillary staging after therapy is not well defined and may be associated with an increase of false negative results in these patients because chemotherapy may influence the standard drainage and, consequently, the responses of metastasis to therapy are different (Vigário et al., 2003).

The absolute contraindications are: clinically positive axilla, core biopsy or fine needle aspiration biopsy with tumoral infiltration, allergy to vital blue dye and/or radiocolloid. The relative contraindications are: previous biopsy or previous axillary surgery to remove some lymph nodes which occur during the procedure reflecting on the tumour's primary site; in these cases, lymphoscintigraphy has a fundamental role, in advanced stages, the tumour's size, multifocal and multicentric disease. Some authors report that age and body mass index also influence in the detection of SL because adipose tissue is supposed to reduce lymphatic fluid in such tissues (Vigário et al., 2003; Filippakis and Zografos, 2007).

The aim of the detection of the SLN is to reduce postoperative morbidity resulting from axillary lymphadenectomy and maintain the correct staging of axilla in breast cancer. Studies which analysed the disease remaining after SLN suggest that this is an efficient method in breast cancer (Konstantiniuk et al., 2007; Janssen et al., 2004). One of the main complications after surgical treatment is upper limb lymphedema. Various studies have been performed comparing the incidence and prevalence of this complication to the surgical technique used. However, the results of these studies must be interpreted cautiously for several reasons. The disease stage in the population undergoing SLN is different from that of the population undergoing axillary lymphadenectomy. In addition, different criteria are used for diagnosing lymphedema. Some authors consider the edema which occurs within the six first years after surgery as a chronic condition (lymphedema). Early edema, however, is usually transitory, does not predispose to chronic lymphedema and its risk factors are distinct (Bergmann et al., 2007).

Studies were included in which the diagnosis of lymphedema was considered (report of weight sensation or arm swelling), thus the incidence in SLN groups ranged from $0 \%$ and $41.7 \%$ and in $\mathrm{AL}$ from $6.7 \%$ and $87.5 \%$ (Schrenk et al, 2000; Burak et al., 2002; Swenson et al., 2002; Schijven et al., 2003). Regarding the aim of the measurement of lymphedema, the incidence ranged from $0 \%$ and $4 \%$ in SLN and $8 \%$ amd $17 \%$ in AL (Sener et al., 2001; Veronesi et al., 2003; Del Bianco et al., 2008; Madson et al., 2008). The average difference between the limbs in SLN ranged from $0.3 \mathrm{~cm}$ to $1.14 \mathrm{~cm}$ and in $\mathrm{AL}$ from $0.27 \mathrm{~cm}$ to 1.50 cm (Schrenk et al, 2000; Burak et al., 2002; Temple et al., 2002). The investigation by Veronesi et al. (2003) was the only randomized study in which many variables shared the same frequency between groups. Swenson et al. (2002) identified differences in tumour characteristic and treatment between the two groups; however similar numbers of patients in both groups underwent radiotherapy. Temple et al. (2002) found that the SLN group underwent radiotherapy (57.3\% and $11.3 \%)$ more often than chemotherapy (38\% and $85 \%$ ). Variations in surgical technique for the identification of sentinel node and the risk of developing lymphedema must be considered and investigated. According to Krynycki et al. (2005), the quality od lymphoscintigraphy influences the exact site of the lymph node. Performing this procedure before SLN may 
decrease the volume of the tissue that must be sectioned, thereby reducing morbidity. Intratumoral injection may cause difficulties in the localization of the sentinel lymph node, increasing surgical manipulation. The surgeon's experience, in localizing the SL, may reduce tissue manipulation. However, little is known about long term SLN morbidity as it is a relatively new surgical technique.

\section{CONCLUSION}

Through the years, the development of surgical techniques has made it possible to minimize deformities. The current trend is that to continue developing techniques that are as conservative as possible. SLN biopsy is prescribed in early tumours, avoiding unnecessary dissection of axillary lymph nodes. Lymphoscintigraphy plays an important role in the identification of the sentinel lymph node, contributing to the prevention and minimization of postoperative complications. However, even with therapeutic changes, lymphedema remains a matter of concern. There are several reasons for this. With the increasing survival, the limitations with which women will be obliged to live can cause psychological, physical, sexual and social issues; axillary lymph node preservation is indicated to tumours up to $3 \mathrm{~cm}$ and a clinically negative axilla. Although the detection of SLN reduces the incidence of lymphedema, it does not eliminate the risk of developing it, mainly those women with other risk factor such as obesity and previous anatomic alterations and; adjuvant treatments, particularly radiotherapy including drainage chains, remains an important risk factor for the development of lymphedema.

Due to the newness of the technique and limited time of follow up, the risk of lymphedema many years after SLN remains unknown. Prospective longitudinal investigations, over time are needed to determine the incidence and risk factors of the various treatments for breast cancer.

\section{ACKNOWLEDGEMENTS}

This study was supported by grants and financial support from UERJ, INCa, CNPq, FAPERJ and Albert Einstein College of Medicine of Yeshiva University.

\section{RESUMO}

O câncer de mama é ainda associado com altas taxas de mortalidade e um dos mais importantes fatores de manutenção de longa sobrevivência é a precisão e o diagnóstico precoce. Em países em desenvolvimento, essa doença freqüentemente é apenas detectada em estágios avançados. Entretanto, através da mamografia, muitas mulheres tiveram o diagnóstico em estágios precoces. Nesse contexto, a técnica do linfonodo sentinela (LNS) está associada com a menor morbidade pós-operatória comparada a linfadenectomia axilar. A linfocintilografia tem emergido como um método para a avaliação das cadeias de drenagem linfática em vários tumores, sendo precisa e não invasiva. O objetivo desse trabalho é apresentar os principais aspectos os quais causam controvérsia sobre LNS e a linfocintilografia e o impacto que esses procedimentos tem tido no linfedema após tratamento cirúrgico para câncer de mama. Uma breve revisão incluindo artigos em inglês, espanhol e português, disponíveis no Lilacs e no Medline, publicados entre janeiro de 2000 e julho de 2008, foi realizada. As palavras-chaves breast cancer, lymphoscintigraphy, SLN biopsy, lymphedema foram usadas. Vários estudos têm objetivado comparar a incidência e prevalência do linfedema de acordo com as técnicas usadas. Entretanto, a população sujeita a LNS é diferente daquela com indicação para linfedenectomia axilar relacionada com o estadiamento. Pouco é conhecido sobre morbidade em longo prazo, uma vez que a técnica é relativamente nova. Concluindo, o desenvolvimento de técnicas cirúrgicas tem permitido minimizar deformidades e a corrente tendência é que essas técnicas sejam tanto conservativas quanto possível. Assim, a linfocintilografia tem papel importante na identificação de LNS, contribuindo para a prevenção e minimização de complicações pósoperatórias. 


\section{REFERENCES}

Bergmann, A.; Koifman, R. J.; Koifman, S.; Ribeiro, M. J. P.; Pedrosa, E.; Mattos, I. E. (2007), Upper limb lymphedema following breast cancer surgery: prevalence and associated factors. Lymphology., 40, 96-106

Bowers, K.; Liu, Y.; Ghesani, N.; Kim, S. H. (2006), A level III sentinel lymph node in breast cancer. World J Surg Oncol., 7, 4:31.

Burak, W. E.; Hollenbeck, S. T.; Zervos, E. E.; Hock, K. L.; Kemp, L. C.; Young, D. C. (2002), Sentinel lymph node biopsy results in less postoperative morbidity compared with axillary lymph node dissection for breast cancer. Am J Surg., 183, 23-27

Cabanas, R. M. (1977), An approach for the Treatment of Penile Carcinoma. Cancer, 39, 456-466.

Czerniecki, B. J.; Bedrosian, I.; Faries, M.; Alavi, A. (2001), Revolutionary impact of lymphocintigraphy and intraoperative sentinel node mapping in the clinical practice of oncology. Sem Nucl Med., 31, 158-164.

Del Bianco, P.; Zavagno, G.; Burelli, P.; Scalco, G.; Barutta, L.; Carraro, P.; Pietrarota, P.; Meneghini, G.; Morbin, T.; Tacchetti, G.; Pecoraro, P.; Belardinelli, V.; De Salvo, G. L. (2008), Morbidity comparation of sentinel lymph node biopsy versus conventional axillary node dissection for reast cancer patients: results of the sentinella-GIVON Italian randomized clinical trial. EJSO., 34, 508-513.

Filippakis, G. M.; Zografos, G. (2007), Contraindications of sentinel lymph node biopsy: Are there any really? World J Surg Oncol., 29, 5-10.

Gould, E. A.; Winship, T.; Philbin, P. H.; Kerr, H. H. (1960), Observations on a "Sentinel Node" in Cancer of the Parotid. Cancer, 13, 77-78.

Instituto Nacional de Câncer (2008), Estimativas 2008. Ministério da Saúde. Accessed in http://www.inca.gov.br.

James, T. A.; Edge, S. B. (2006), Sentinel lymph node in breast câncer. Curr Opin Obstet Gynecol., 18, 5358.

Janssen, S. M. M.; Smidt, M. L.; Bruggink, E. D.; Strobbe, L. J. (2004), Axillary recurrences after negative sentinel node biopsy for breast cancer: incidence and clinical relevance. Ann Surg Oncol., 11, 276.

King, T. A.; Fey, J. V.; Zee, K. J. V.; Heerdt, A. S.; Gemignani, M. L.; Port, E. R. (2004), A prospective analysis of the effect of blue-dye volume on sentinel lymph node mapping success and incidence of allergic reaction in patients with breast cancer. Ann Surg Oncol., 11, 535-541.
Konstantiniuk, P.; Schrenk, P.; Reitsamer, R.; Koeberle-Wuehrer, R.; Tausch, C.; Roka, S.; Riedl, O.; Poestlberger, S.; Hecke, D.; Janauer, M.; Haid, A. (2007), A nonrandomized follow-up comparison between standard axillary node dissection and sentinel node biopsy in breast cancer. The Breast., 16, 520-526.

Krynycki, B. R.; Kim, S. C.; Kim, C. K. (2005), Preoperative lymphocintigraphy and triangulated patient body marking are important parts of the sentinel node process in breast cancer. World J Surg Oncol., 3, 1-4.

Madson, A. H.; Haugaard, K.; Soerensen, J.; Bokmand, S.; Friis, E.; Holtveg, H.; Garne, J. P.; Horby, J.; Christiansen, P. (2008), Arm morbidity following sentinel lymph node biopsy or axillary lymph node dissection: a study from the Danish Breast cancer Cooperative Group. The Breast., 17, 138-47.

Massod, S. (2006), Micrometastases in lymph node. B C O., 9, 1-3.

McMasters, K. M.; Wong, S. L.; Tuttle, T. M.; Carlson, D. J.; Brown, C. M.; Noyes, R. D. (2000), Preoperative Lymphocintigraphy for Breast Cancer Does Not Improve the Ability to Identify Axillary Sentinel Nodes. Ann Surg., 231, 724-731.

Noguchi, M.; Tsugawa, K.; Bando, E.; Kawahara, F.; Miwa, K.; Yokoyama, K. (2004), Current controversies concerning sentinel lymph node biopsy for breast cancer. Breast Cancer Res Treat., 84, 26171.

Olmos, R. A. V.; Hoefnagel, C. A.; Nieweg, O. E.; Jansen, L.; Rutgers, E. J. T.; Borger, J. (1999), Lymphocintigraphy in oncology: a rediscovered challenge. Eur J Nucl Med., 26, S2-S10.

Sado, N. S. (2006), Linfocintilografia após cirurgia de mamoplastia de aumento por técnica transaxilar endoscópica: avaliação do padrão de drenagem linfática mamária e possível impacto nos índices de identificação do linfonodo sentinela [dissertação]. Setor de Ciências da Saúde: Universidade Federal do Paraná.

Schijven, M. P.; Vingerhoets, A. J.; Rutten, H. J.; Nieuwenhuijzen, G. A.; Roumen, R. M.; van Bussel, M. E.; Voogd, A. C. (2003), Comparison of morbidity between axillary lymph node dissection and sentinel node biopsy. Eur J Surg Oncol.,. 29, 341-350.

Schrenk, P.; Rieger, R.; Shamiyeh, A.; Wayand, W. (2000), Morbidity following sentinel lymph node biopsy versus axillary lymph node dissection for patients with breast carcinoma. Cancer., 88, 608-614

Sener, S. F.; Winchester, D. J.; Martz, C. H.; Feldman, J. L.; Cavanaugh, J. A.; Winchester, D. P. (2001), Lymphedema after sentinel lymphadenectomy for breast carcinoma. Cancer., 92, 748-52. 
Stanton, A. W.; Modi, S.; Mellor, R. H.; Peters, A. M.; Svensson, W. E.; Levick, J. R.; Mortimer, P. S. (2006), A quantitative lymphoscintigraphic evaluation of lymphatic function in the swollen hands of woman with lympho edema following breast cancer treatment. Clin. Sci (lond)., 110, 553-61.

Swenson, K. K.; Nissen, M. I.; Ceronsky, C.; Swenson, L.; Lee, M. W.; Tuttle, T. M. (2002), Comparison of side effects between sentinel lymph node and axillary lymph node dissection for breast cancer. Ann Surg Oncol., 9, 745-53.

Temple, L. K. F.; Baron, R.; Cody, H. S.; Fey, J. V.; Thaler, H. T.; Borgen, P. I. (2002), Sensory morbidity after lymph node biopsy and axillary dissection: a prospective study of 233 woman. Ann Surg Oncology., 9, 654-662.
Veronesi, U.; Paganelli, G.; Viale, G.; Parh, F. R. C.; Luini, A.; Zurrida, S. (2003), A randomized comparison of sentinel-node biopsy with routine axillary dissection in breast cancer. NEJM., 349, 54653.

Vigário, A.; Sapienza, M. T.; Sampaio, A. P.; Piato, J. R.; Barros, N.; Barros, A. et al. (2003), Primary Chemotherapy Effect in Sentinel Node Detection in Breast Cancer. Clin Nucl Med., 28, 553-557.

Received: August 28, 2008; Revised: September 16, 2008; Accepted: September 18, 2008 